\title{
THE CHOLESTEROL-ESTERIFYING ENZYME OF HUMAN SERUM. I. IN LIVER DISEASE ${ }^{1}$
}

\author{
By KENNETH B. TURNER, GEORGE H. MCCORMACK, JR., AND ANNE RICHARDS \\ (From the Department of Medicine, College of Physicians and Surgeons, Columbia University, \\ Presbyterian Hospital, New York City, N. Y.)
}

(Submitted for publication November 6, 1952; accepted May 1, 1953)

The presence of an enzyme in normal human blood serum capable of esterifying cholesterol in vitro was first reported by Sperry (1). He found that when serum was incubated its free cholesterol decreased while the total cholesterol was unchanged. It was concluded that esterification of some of the free cholesterol had taken place through the action of an enzyme, as the effect was abolished by heating the serum to 55 to $60^{\circ} \mathrm{C}$. prior to incubation. Hemolysis also inhibited the reaction as did bile salts.

It seemed probable that the liver might be connected in some way with the production of this enzyme, as the ratio of free to ester cholesterol in the serum is often abnormal in hepatic disorders. Therefore, in some types of liver disease decreased enzyme activity might be expected. This was indeed found to be the case and a preliminary report on a small series of patients was made in 1949 (2). Similar results were published simultaneously from the University of Madrid (3).

The behavior of this enzyme has been studied in 254 patients with liver disease and an attempt has been made to determine wherein this test may supplement other tests of liver function.

\section{METHODS}

Blood was obtained from 20 normal subjects serving as controls and from 254 patients with liver disease divided as follows: Acute hepatitis-76; chronic hepatitis-19; cirrhosis-69; biliary tract disease-45; carcinoma of pancreas or biliary tract-21; Hodgkin's disease and metastatic carcinoma of the liver-17; miscellaneous liver disease-7. As a rule multiple samples were secured from each individual to determine enzyme activity throughout the course of the disease. Blood was usually drawn from the fasting subject. Samples that were visibly hemolyzed were discarded because of the inhibiting effect of hemolysis on enzyme activity.

1 This investigation was aided by research grant $\mathrm{H} 39$ from the National Heart Institute, U. S. Public Health Service.
The amount of total and free cholesterol in a sample of serum was determined by the method of Schoenheimer and Sperry (4) before and after incubation of the serum at $37^{\circ} \mathrm{C}$. for 24 hours. The difference between the values for free and total cholesterol was assumed to represent cholesterol ester. With incubation the amount of free cholesterol usually fell. The percentage decrease was calculated. As a matter of convenience this drop has been expressed by enzyme units. One unit is defined as the amount of enzyme activity capable of producing a one per cent decrease in the original level of free cholesterol.

Other tests of liver function used for comparison were the serum bilirubin, alkaline phosphatase, and cephalin flocculation. These were performed in the laboratory for routine chemistry by standard methods.

The following were accepted as normal values for the serum: total cholesterol, 150-300 mg. per cent; ester cholesterol, 70 per cent or more of the total; activity of the cholesterol-esterifying enzyme, 30 units or more; bilirubin, less than $1.0 \mathrm{mg}$. per cent; alkaline phosphatase, less than 6.0 Bodansky units. The cephalin flocculation is normally negative.

\section{Normal Subjects}

In 20 normal subjects the total serum cholesterol ranged from 156 to $268 \mathrm{mg}$. per cent, of which 71 to 75 per cent was esterified. The free cholesterol before incubation ranged from 40 to $75 \mathrm{mg}$. per cent. With incubation, enzyme action caused a drop of 31 to 50 per cent (31 to 50 units) in the free cholesterol. In 17 of of the 20 subjects the decrease was 33 to 44 units.

\section{Hepatitis}

There were 76 patients with viral hepatitis. About 25 to 30 per cent of these were probably homologous serum hepatitis. From the standpoint of enzyme activity there was no apparent difference between patients with infectious hepatitis and those considered to have homologous serum hepatitis.

Enzyme activity varied according to the week of the disease as shown in Figure 1. Admitting the obvious difficulty in determining the duration of the disease with its insidious onset, enzyme activity was always low in the first week of hepatitis. During the second week 32 of 39 blood samples also had low enzyme activity. Thereafter enzyme activity returned to normal so that in the fourth week, normal values were obtained in 21 


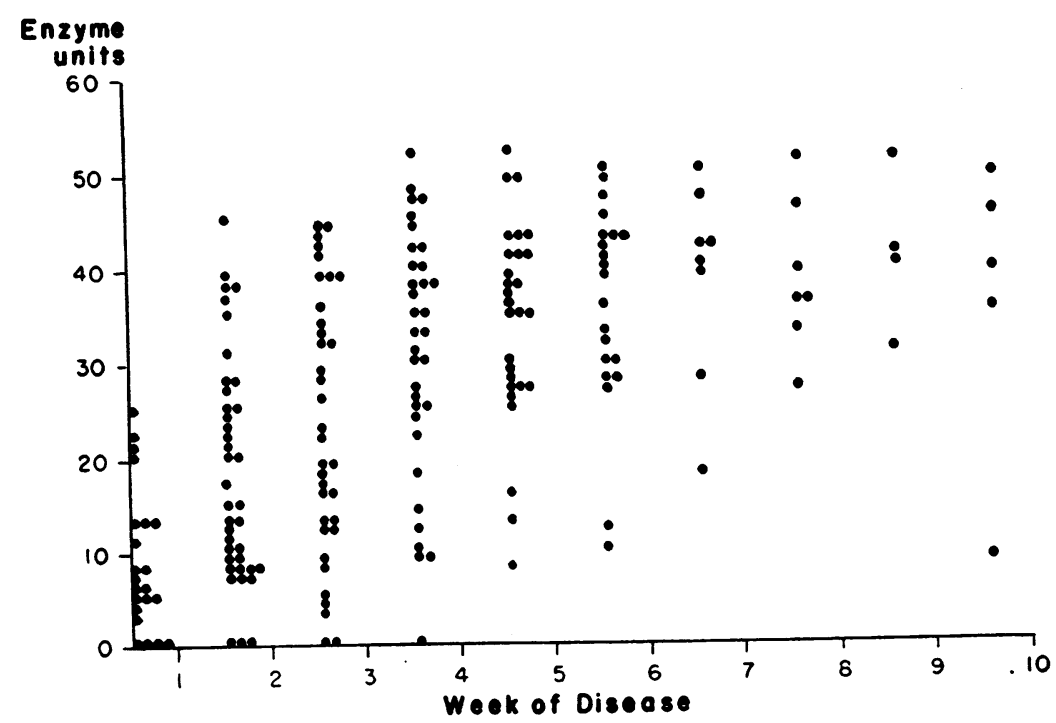

Fig. 1. Enzyme Activity in Viral Hepatitis According to the Duration of THE Disease

Each dot represents one determination.

of 34 samples and in the sixth week in 16 of 21 samples. An increase in enzyme activity of 25 or 30 units in a week or two was not uncommon. The greatest increase encountered was a rise from 7 enzyme units to 42 units in one week.

The return of enzyme activity to normal occasionally preceded other evidence of improvement. The finding of normal enzyme activity early in the disease was a good prognostic sign. Increasing enzyme activity was associated with a good prognosis; falling enzyme activity with a poor prognosis. Only one patient who showed a significant fall in enzyme activity recovered. This is included in Figure 2 which shows typical examples of fluctuations in enzyme activity.

There were eight deaths in this group of 76 patients. All of the fatalities occurred in patients who had less than 10 enzyme units in the serum. On the other hand $23 \mathrm{pa}$ tients with less than 10 enzyme units recovered.

In hepatitis when a normal percentage of esterified cholesterol was found, normal enzyme activity was encountered except in one case with 27 enzyme units. However, normal enzyme activity was noted in 15 patients in whom the proportion of esterified cholesterol was subnormal (below 70 per cent). Enzyme activity which


Fig. 2. Examples of Repeated Determinations of Enzyme Activity in Selected Patients with Viral Hepatitis

A rise in enzyme units was associated with a good prognosis; a significant fall with a poor prognosis, with the exception illustrated. 
TABLE 1

Chemical data on hepatitis patients with negative or slightly positive cephalin flocculation tests

\begin{tabular}{|c|c|c|c|c|c|c|c|c|}
\hline Case & Sex & Age & $\underset{\text { bilirubin }}{\text { Serum }}$ & $\begin{array}{c}\text { Cephalin } \\
\text { flocculation }\end{array}$ & $\begin{array}{c}\text { Alkaline } \\
\text { phosphatase }\end{array}$ & $\begin{array}{c}\text { Total } \\
\text { cholesterol }\end{array}$ & $\begin{array}{c}\text { Cholesterol } \\
\text { ester }\end{array}$ & $\begin{array}{c}\text { Enzyme } \\
\text { units }\end{array}$ \\
\hline $\begin{array}{r}1 \\
2 \\
3 \\
4 \\
5 \\
6 \\
7 \\
8 \\
9 \\
10 \\
11 \\
12\end{array}$ & $\begin{array}{l}\mathbf{F} \\
\mathbf{F} \\
\mathbf{F} \\
\mathbf{M} \\
\mathbf{M} \\
\mathbf{M} \\
\mathbf{M} \\
\mathbf{F} \\
\mathbf{M} \\
\mathbf{M} \\
\mathbf{M} \\
\mathbf{M}\end{array}$ & $\begin{array}{l}41 \\
18 \\
35 \\
28 \\
28 \\
43 \\
18 \\
18 \\
50 \\
51 \\
27 \\
39\end{array}$ & $\begin{array}{r}m g . \% \\
4.3 \\
3.1 \\
21.0 \\
6.5 \\
3.6 \\
11.8 \\
11.2 \\
18.2 \\
3.2 \\
16.4 \\
16.5 \\
17.1\end{array}$ & $\begin{array}{l} \pm \\
0 \\
0 \\
0 \\
0 \\
0 \\
0 \\
+ \\
0 \\
0 \\
0 \\
0\end{array}$ & $\begin{array}{r}B . U . \\
24.9 \\
10.1 \\
3.8 \\
14.7 \\
6.7 \\
7.7 \\
1.1 \\
7.3 \\
10.7 \\
8.4 \\
7.1 \\
11.1\end{array}$ & $\begin{array}{c}\boldsymbol{m g} . \% \\
615 \\
319 \\
268 \\
285 \\
238 \\
129 \\
254 \\
222 \\
234 \\
250 \\
279 \\
252\end{array}$ & $\begin{array}{l}\% \\
15 \\
72 \\
30 \\
27 \\
30 \\
39 \\
28 \\
30 \\
30 \\
40 \\
26 \\
50\end{array}$ & $\begin{array}{r}0 \\
27 \\
10 \\
17 \\
25 \\
9 \\
12 \\
19 \\
13 \\
22 \\
11 \\
19\end{array}$ \\
\hline
\end{tabular}

was rising might become normal 4 to 14 days before a normal serum cholesterol partition was found.

In 64 of the 76 patients with hepatitis the determination of enzyme activity added nothing diagnostically as the disease was clearly evident. All of these 64 patients had a positive cephalin flocculation and an elevated serum bilirubin. In a number of cases there was an increase in serum alkaline phosphatase or serum globulin. However, in the remaining 12 cases, the determination of enzyme activity proved diagnostically helpful. In these the cephalin flocculation test was negative in 10 and faintly positive in 2 . Significant data on these 12 patients are given in Table $I$.

In Case 1 surgical exploration was planned but deferred because of the absence of enzyme activity. Within six weeks the patient felt well and the serum bilirubin had fallen nearly to normal as had the phosphatase. The serum cholesterol had dropped to $441 \mathrm{mg}$. per cent, the enzyme units had risen to 21 , and the cephalin flocculation had become $3+$. Recovery thereafter was uneventful. Case 2 was improving when first seen and the enzyme units were nearly normal. This was also true of Case 5. Case 3 was treated conservatively and improved promptly. On Case 4 a laparotomy was performed for possible biliary tract obstruction. None was found. Autopsy revealed a viral hepatitis. Case 6 was also operated upon and died shortly thereafter. Biopsy and autopsy showed a virus hepatitis. Cases 7 and 8 , both homologous serum hepatitis, improved steadily. Cases 9 to 12 were diagnosed pericholangitic hepatitis on biopsy.

\section{Chronic Hepatitis}

In 19 patients with this diagnosis 11 had less than 30 units of enzyme, and 8 had normal enzyme activity. The decrease in enzyme activity was less marked than in acute hepatitis. Four patients had less than 20 enzyme units, and in 7 the values ranged from 21 to 29 units.

The serum bilirubin, alkaline phosphatase, and globulin were usually increased. Three of the group had negative cephalin flocculation tests. The enzyme activity was normal in two of these but in one it was only 13 units.
This patient ultimately died of hepatic insufficiency. The percentage of cholesterol esters was less than 70 per cent in 18 patients, of whom 11 had decreased enzyme activity and 7 had normal amounts of enzyme. The single patient with a normal proportion of esterified cholesterol had 40 units of enzyme.

In chronic hepatitis, as in acute hepatitis, enzyme activity of less than 10 units seemed of prognostic significance. There were two deaths. Shortly prior to death, one of these patients had 9 enzyme units and the other only 1 unit. One patient who had 9 enzyme units on admission gradually improved.

\section{Cirrhosis}

Low enzyme activity was found in 42 and normal activity in 27 of 69 patients with Laennec's cirrhosis. In general, the more severely damaged the liver, as shown by other liver function tests, the more likely was decreased enzyme activity to be found (Table II). While there was a general correlation between enzyme activity and the percentage of esterified cholesterol in the serum, it was not exact. In eight patients with a normal ratio of

TABLE II

Laennec's cirrhosis

\begin{tabular}{|c|c|c|c|}
\hline \multirow{2}{*}{ Number of cases: } & & \multicolumn{2}{|c|}{ Enzyme activity } \\
\hline & & Low & $\underset{27}{\text { Normal }}$ \\
\hline Total cholesterol & $\begin{array}{l}\text { - low } \\
\text { normal } \\
\text { high }\end{array}$ & $\begin{array}{r}18 \\
18 \\
6\end{array}$ & $\begin{array}{r}7 \\
19 \\
1\end{array}$ \\
\hline Per cent esterified cholesterol & -low & 34 & 11 \\
\hline Serum bilirubin & $\begin{array}{l}\text { normal } \\
\text {-increased } \\
\text { normal }\end{array}$ & $\begin{array}{r}8 \\
32 \\
9\end{array}$ & $\begin{array}{r}16 \\
14 \\
9\end{array}$ \\
\hline Cephalin flocculation & $\begin{array}{l}\text { positive } \\
\text { negative }\end{array}$ & $\begin{array}{l}29 \\
11\end{array}$ & $\begin{array}{l}14 \\
12\end{array}$ \\
\hline Serum alkaline phosphatase & $\begin{array}{l}\text {-increased } \\
\text { normal }\end{array}$ & $\begin{array}{r}8 \\
31\end{array}$ & $\begin{array}{r}8 \\
16\end{array}$ \\
\hline Albumin/globulin ratio & $\begin{array}{l}\text {-abnormal } \\
\text { normal }\end{array}$ & $\begin{array}{l}20 \\
10\end{array}$ & $\begin{array}{l}13 \\
10\end{array}$ \\
\hline
\end{tabular}


TABLE III

Biliary tract disease

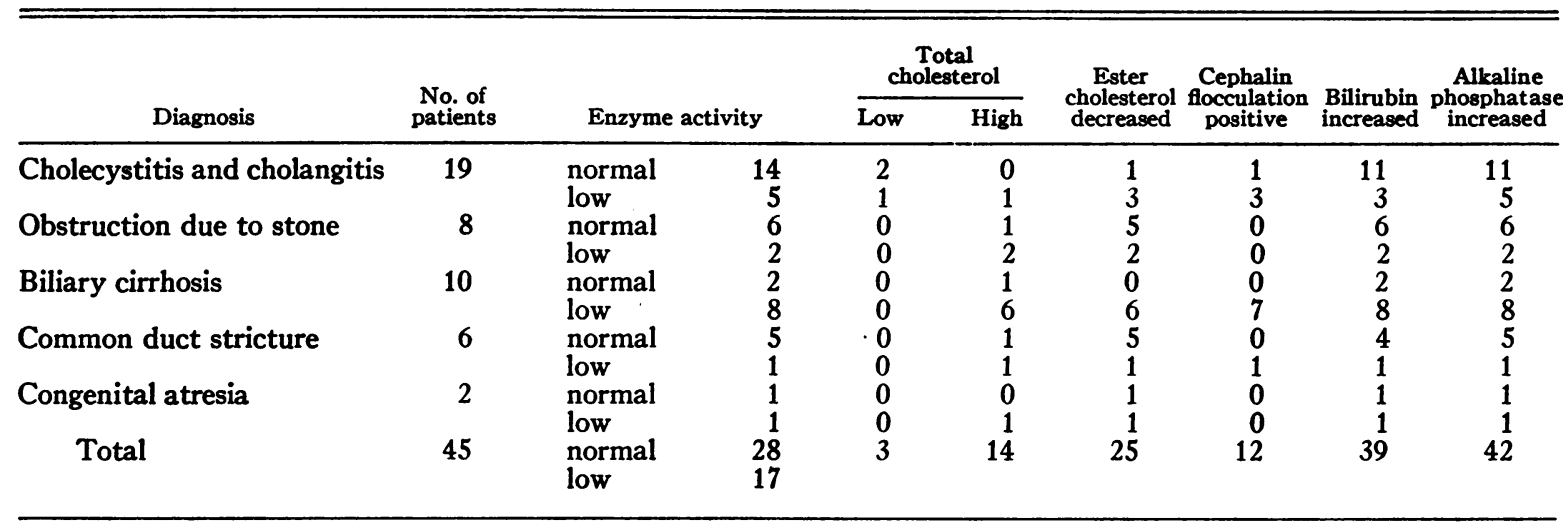

cholesterol ester, low enzyme activity was detected, while in 11 patients with a decreased percentage of ester, normal enzyme values were obtained.

In this disease there was very little correlation between the cephalin flocculation and enzyme activity. The flocculation test was positive in 43 patients, 29 of whom had decreased and 14 normal amounts of enzyme. In the 23 cases with negative cephalin flocculation, 12 had normal and 11 decreased enzyme activity.

Enzyme activity appears not to have diagnostic value in cirrhosis. From the standpoint of prognosis, however, determination of enzyme activity may be of value. There were 11 deaths in this series. In two instances enzyme activity was normal. Both of these patients died from ruptured esophageal varices. In nine of the fatal cases enzyme activity was low. Death was due to hepatic insufficiency in seven of these, to hemorrhage in one, and to primary liver carcinoma in the remaining case.

\section{Biliary Tract Disease}

The 45 patients in this group were subdivided as follows: Cholecystitis and cholangitis-19 cases; obstructive jaundice due to common duct stone -8 cases; biliary cirrhosis-10 cases; cicatricial stricture of the common duct -6 cases; congenital atresia of bile ducts-2 cases (Table III). It was realized that this separation at times was arbitrary and that overlap might occur.

Decreased enzyme activity was noted in 17 . This reduction was slight (26 to' 28 enzyme units) in cholecystitis. In general, the lowered enzyme activity paralleled a positive cephalin flocculation test and probably was the result of biliary cirrhosis.

High levels of total serum cholesterol were found in biliary cirrhosis and with obstruction due to an increase in free cholesterol and a corresponding decrease in esterified cholesterol. There was poor correlation between decreased enzyme activity and a low cholesterol ester fraction.

The serum alkaline phosphatase was high in 42 and the serum bilirubin in 39 .

\section{Obstructive Jaundice Due to Neoplasm}

There were 21 patients with jaundice resulting from an obstructing neoplasm; pancreatic carcinoma in 14, carcinoma of bile duct in 2 , and of gall bladder in 2 . The remaining 3 cases were carcinoma of stomach, lymphosarcoma, and a benign papilloma of the common bile duct.

The serum bilirubin and alkaline phosphatase were increased in all. The cephalin flocculation test was negative in 18, positive in 1 , and not done in 2 . Total serum cholesterol values were high in 15 . The percentage of esterified cholesterol was subnormal in 19. Enzyme activity was decreased in 16 .

\section{Hodgkin's Disease and Metastatic Involvement of Liver}

Of the 17 patients in this group, enzyme activity was decreased in 7. The total serum cholesterol was low in 6, high in 6. Esterified cholesterol was decreased in 13.

Two patients had only cholesterol determinations and no other liver function tests. In the remaining 15 cases, the cephalin flocculation test was positive in 6 , the serum bilirubin elevated in 6 , and the alkaline phosphatase was high in 13.

\section{Miscellaneous Liver Disease}

There were seven patients in this group. Three of these had liver abscess. There was one case of each of the following: infectious mononucleosis, miliary tuberculosis, carbon tetrachloride poisoning, cavernomatous transformation of the portal vein. These cases are obviously too few for detailed analysis. Enzyme activity was normal in all.

\section{DISCUSSION}

It may fairly be asked whether determination of the activity of the cholesterol esterifying enzyme yields diagnostic information beyond that af- 
forded by the usual serum cholesterol partition. We believe that the answer is in the affirmative in a number of situations.

There are two ways in which a decreased proportion of esterified cholesterol in the serum may arise: 1) an actual decrease in the amount of cholesterol ester without a corresponding decrease in free cholesterol, or 2) an actual increase in the amount of free cholesterol without a corresponding increase in ester cholesterol. Determination of enzyme activity helps to differentiate between these two causes of a low percentage of esterified cholesterol. This is particularly true in obstructive jaundice due to gall-stones where the percentage of ester cholesterol is usually low as a result of an accumulation of free cholesterol in the blood. In these cases the enzyme activity is usually normal. Less often this is seen with an obstructing carcinoma, chronic hepatitis or biliary tract disease. In cirrhosis the lack of correlation between enzyme activity and the ratio of cholesterol ester should be emphasized. Furthermore, in the course of acute hepatitis the return to normal of enzyme values before the restitution of a normal cholesterol partition is of interest.

The value of the determination of enzyme activity in the prognosis of hepatitis and cirrhosis has been stressed. All the deaths due to acute or chronic hepatitis in this series have occurred in patients with less than 10 enzyme units in the serum. All deaths due to hepatic insufficiency in the patients with Laennec's cirrhosis have also occurred in the group with low enzyme activity.

The diagnostic applications of the test may be summarized as follows: Decreased enzyme activity is found uniformly in the early stages of acute hepatitis. In most instances the diagnosis is apparent without the aid of the determination of enzyme activity, particularly as a positive cephalin flocculation test points strongly to damage of the liver parenchyma. However, in 12 of the 76 cases of hepatitis the cephalin flocculation test was negative and the finding of low enzyme values in these cases threw the weight of diagnostic evidence toward hepatitis. Included in this category were the four cases of pericholangitic hepatitis.

In chronic hepatitis low levels of enzyme activity are often found but this does not help to differentiate the condition from cirrhosis, either portal or biliary. In Laennec's cirrhosis, the serum of about 60 per cent of the patients shows decreased enzyme activity but this is not a diagnostic aid as a rule. In biliary cirrhosis 8 of the 10 patients were found to have decreased activity of the enzyme.

In contrast to hepatitis and cirrhosis enzyme activity was usually normal in cholecystitis, cholangitis, obstructive jaundice due to gall-stones, and cicatricial deformity of the common ducts. However, in obstructive jaundice due to neoplasm decreased enzyme activity was noted in 16 of the 21 cases.

It had been hoped originally that the determination of enzyme activity would serve to differentiate between parenchymal liver disease and extrahepatic obstruction. While this proved to be true in disease of the biliary tree other than neoplasm, its failure in obstructive jaundice due to tumor proved disappointing. Some type of inhibiting substance in the serum has been postulated. It seemed possible that this might be cholic acid as Sperry (1) had shown that bile salts would inhibit the activity of the enzyme. So far, we have not been able to demonstrate that this is the mechanism involved in these cases.

In analyzing further the patients with obstructive jaundice due to neoplasm whose serum showed decreased enzyme activity, an interesting tetrad of chemical findings emerged. In 12 of the 16 patients the following combination was found: 1) serum bilirubin $10 \mathrm{mg}$. per cent or more; 2) serum alkaline phosphatase 10 Bodansky units or more; 3 ) total serum cholesterol $300 \mathrm{mg}$. per cent or more; 4) negative cephalin flocculation. In the remaining 238 cases in the total series, this tetrad was encountered in only six. Four of the six patients had obstructive jaundice due respectively to neoplasm, cicatrix, stone, and congenital atresia of the bile ducts. (The patient with the neoplasm had normal enzyme activity.) One patient was diagnostically puzzling but finally classified as having biliary cirrhosis. In the sixth patient who had viral hepatitis, the tetrad was found transiently a week or two before death. Thus in the 18 cases with this tetrad, a surgical condition was present in 16. 


\section{SUM MARY}

1. Observations on the activity of the cholesterol-esterifying enzyme have been made in 254 cases of liver disease.

2. In hepatitis, enzyme activity was uniformly low early in the course of the disease. Determination of enzyme activity was of diagnostic value in the 16 per cent of the cases in this group who had negative cephalin flocculation tests. Prognostically, decreasing enzyme activity was an ominous sign. All the deaths in this group occured in patients with less than ten enzyme units.

3. Diminished enzyme activity was found in 42 of 69 cases of Laennec's cirrhosis. The test had little diagnostic value in this condition but from a prognostic standpoint it was noted that deaths from hepatic insufficiency all occurred in the group with low enzyme activity.

4. In biliary cirrhosis, enzyme activity was usually low.

5. Normal enzyme activity was usually found in patients with cholecystitis, cholelithiasis and common duct stricture. The test was often of diagnostic value in these conditions.
6. In 16 of 21 cases of obstructive jaundice due to neoplasm enzyme activity was decreased. In 12 of the 16 there was encountered a tetrad consisting of : serum bilirubin above $10 \mathrm{mg}$. per cent, alkaline phosphatase above 10 Bodansky units, total cholesterol above $300 \mathrm{mg}$. per cent, and a negative cephalin flocculation test. This combination was found in only six other patients and four of these had obstructive jaundice. Thus, of the 18 patients showing the tetrad, extrahepatic obstructive jaundice was present in 16 .

\section{REFERENCES}

1. Sperry, W. M., Cholesterol esterase in blood. J. Biol. Chem., 1935, 111, 467.

2. Turner, K. B., and Pratt, V., Effect of incubation on the cholesterol partition in human serum. Proc. Soc. Exper. Biol. \& Med., 1949, 71, 633.

3. Castro Mendoza, H., and Jimenez Diaz, C., The cholesterase of the serum (Sperry's enzyme) under normal and pathological conditions. Bull. Inst. Med. Research, Univ. Madrid, 1949, 2, 81.

4. Schoenheimer, R., and Sperry, W. M., A micromethod for the determination of free and combined cholesterol. J. Biol. Chem., 1934, 106, 745. 